\title{
Pênfigo foliáceo em cabra Boer
}

\author{
Pemphigus foliaceous in a Boer goat
}

\author{
Juliana Targino Silva Almeida Macêdo ${ }^{\mathrm{I}}$ Franklin Riet-Correa ${ }^{\mathrm{I} *}$ \\ Antônio Flávio Medeiros Dantas ${ }^{\mathrm{I}}$ Sara Vilar Dantas Simões ${ }^{\mathrm{I}}$
}

\section{- NOTA -}

\section{RESUMO}

Pênfigo foliáceo é uma doença auto-imune crônica da pele observada com freqüência em cães e, com menor freqüencia, em outras espécies animais. Neste trabalho é descrito um caso desta enfermidade no semiárido da Paraíba, em uma cabra da raça Boer, que apresentava lesões crônicas de pele com extensas áreas alopécicas irregulares, esfoliativas, com crostas amareladas e bilaterais que afetavam a região dorsal da escápula, do tórax, do dorso, da parede do abdominal, da garupa, dos membros pélvicos e da cauda. No rodete coronário, havia espessamento da pele e lesões crostosas. Microscopicamente foram observadas hiperqueratose, espongiose e pústulas intracorneais ou subcornais afetando epiderme $e$ infundíbulos. Nas pústulas, havia grande quantidade de neutrófilos, eosinófilos e células acantolíticas. Na derme, havia acentuada congestão e moderado infiltrado inflamatório composto por eosinófilos, raros plasmócitos, linfócitos e macrófagos, principalmente na periferia de capilares e nos folículos pilosos. Os achados macro e microscópicos são característicos de pênfigo foliáceo. Esta enfermidade é rara em caprinos e, provavelmente, este seja o primeiro relato da doença no Brasil.

Palavras-chave: pênfigo foliáceo, caprinos, doenças da pele, patologia.

\section{ABSTRACT}

Pemphigus foliaceous is an autoimmune disease of the skin affecting mainly dogs and, with less frequency, other domestic species. A case of this disease is reported in the semiarid of Paraiba, Brazil, in a Boer goat with chronic skin lesions with extensive bilateral exfoliatives areas of alopecia, with yellowish crusts affecting the dorsal scapular region, thorax, abdominal wall, croup, hindlimbs and tail. On the coronary band of the hoofs, thick crusts were observed. Microscopiacally, there were hyperkeratosis, spongiosis, intracorneal and sucorneal pustules affecting the epidermis and follicular infundibula. Large number of neutrophils, eosinophils and acantholitic cells were observed in the pustules. The dermis had congestion and mild infiltration of eosinophils, rare plasma cells, lymphocytes and macrophages, mainly in the periphery of follicles. Gross and histologic lesions are characteristic of pemphigus foliaceous, an uncommon disease of goats. This seems to be the first report of pemphigus foliaceous in goats in Brazil.

Key words: pemphigus foliaceous, goats, skin diseases, pathology.

Pênfigo é um complexo de doenças autoimunes crônicas da pele, caracterizadas por acantólise e pela presença de vesículas ou bolhas e subseqüentemente erosões e ulcerações (HARGIS \& GINN, 2007). Nos animais, podem ser observadas várias formas de manifestação desta doença: pênfigo vulgar, pênfigo vegetante, pênfigo foliáceo, pênfigo paraneoplásico e pênfigo eritematoso (GROSS et al., 1992; HARGIS \& GINN, 2007). O pênfigo vulgar, que é a forma mais grave, ocorre em cães e gatos, apresentando lesões vesiculares ou bolhosas, seguidas de erosões e úlceras na cavidade oral, nas junções mucocutâneas, nas axilas e na virilha e caracteriza-se microscopicamente por formação de vesículas suprabasais. O pênfigo vegetante ocorre raramente em cães e é uma forma leve do pênfigo vulgar. Ele se

IHospital Veterinário, Centro de Saúde e Tecnologia Rural, Universidade Federal de Campina Grande (UFCG), Campus de Patos, 58700-970, Patos, PB, Brasil. E-mail: franklin.riet@pq.cnpq.br. *Autor para correspondência. 
caracteriza por vesículas e pústulas na epiderme e durante a cicatrização há hiperplasia epidérmica, que resulta em proliferação papilomatosa (HARGIS \& GINN, 2007). O pênfigo foliáceo é mais brando e mais comum do que o pênfigo umectante e ocorre em cães, gatos, cavalos e caprinos (RADOSTITS et al., 2000; OLIVRY, 2006). Em um estudo nos EUA, no período de 19751984, a incidência anual de pênfigo foliáceo em cães e gatos foi de $0,3 \%$ e $5 \%$, respectivamente (OLIVRY, 2006). Nas espécies eqüina e felina, a doença foi menos freqüente, apresentando 0,05\% e 0,1\% de incidência, respectivamente (OLIVRY, 2006). No Brasil, há descrições de pênfigo foliáceo em cavalos (OLIVEIRA FILHO et al., 2007, MONTEIRO et al., 2007). Em caprinos, a ocorrência é rara, sendo que foram encontrados somente quatro casos na literatura (JACKSON et al., 1984; SCOTT et al., 1984; VALDEZ et al., 1995; PAPPALARDO et al., 2002). Pênfigo paraneoplásico e pênfigo eritematoso são de ocorrência rara (GROSS et al., 1992; HARGIS \& GINN, 2007)

No pênfigo foliáceo, há o desenvolvimento de auto-anticorpos, tipicamente IgG, contra componentes dos desmossomas e das moléculas glicoproteícas de superfície dos queratinócitos da pele. Quando estes anticorpos se ligam aos antígenos intercelulares, as células epidérmicas internalizam o complexo antígenoanticorpo, o que faz com que os queratinócitos afetados sintetizem e secretem o ativador do plasminogênio. Essa ativação leva à destruição dos desmossomos, ocorrendo perda de coesão entre as células epidérmicas (acantólise), que resulta em fissuras, vesículas e bolhas intraepidérmicas. As células acantolíticas assumem uma forma esférica e são encontradas livres dentro da vesícula ou da pústula epidérmica. O citoplasma destes queratinócitos esferóides tipicamente torna-se mais eosinofílico que os normais, mas essas células continuam viáveis (JONES et al., 2000).

As lesões, que com freqüência exibem simetria bilateral, são caracterizadas por áreas de alopecia com prurido, descamação e pústulas. Às vezes ocorre formação de grandes crostas localizadas na cabeça, na orelha, no pescoço, no dorso, na superfície ventral do abdômen, na virilha e na cauda (JACKSON et al., 1984; PAPPALARDO et al., 2002). Histologicamente podem ser observados hiperqueratose ortoqueratótica lamelar, hiperplasia epidermal irregular e formação de microabscessos ou vesículas intraepidérmicas com presença de células acantolíticas, inúmeros eosinófilos e células polimorfonucleares e mononucleares (JACKSON et al., 1984). Na derme superficial observa-se infiltrado inflamatório misto perivascular ou intersticial, constituído principalmente por neutrófilos e eosinófilos, além de macrófagos, linfócitos e plasmócitos, acompanhados por edema, ectasia vascular e congestão (GROSS et al., 1992). O diagnóstico pode ser baseado no histórico de dermatite crônica, com áreas alopécicas e prurido, confirmado por histopatologia (PAPPALARDO et al., 2002). Pela imunofluorescência, imunoistoquímica ou microscopia eletrônica podem ser detectados depósitos de IgG nos espaços intercelulares e na superfície dos queratinócitos (JONES et al., 2000)

Descreve-se um caso de pênfigo foliáceo em uma cabra da raça Boer, de dois anos e oito meses de idade, com histórico de dermatite crônica, trazida ao Hospital Veterinário da Universidade Federal de Campina Grande, em Patos, Paraíba. No exame clínico, foram observadas extensas áreas alopécicas, bilaterais e simétricas na pele da região dorsal da escápula, no tórax, na parede abdominal, no dorso, na garupa, nos membros pélvicos e na cauda (Figura 1A). Essas lesões eram acentuadas na região dorso-lombar e caracterizavam-se por esfoliações com crostas amareladas. No rodete coronário havia espessamento da pele e formações de crostas (Figura 1B). O animal apresentava prurido. Biópsia de pele foi realizada e fragmentos foram processados rotineiramente para avaliação histológica. Em seções de pele coradas pela hematoxilina e pela eosina, foram observadas hiperqueratose, espongiose, degeneração hidrópica com formação de vesículas e pústulas intracorneais (Figura 1C) ou subcorneais (intragranulares) na epiderme e nos infundíbulos dos folículos pilosos. Nas pústulas havia grande quantidade de neutrófilos, eosinófilos e queratinócitos com citoplasmas eosinofílicos e esferoidais, característicos de células acantolíticas (Figura 1D). Na derme havia acentuada congestão e moderado infiltrado inflamatório composto por eosinófilos e raros plasmócitos, linfócitos e macrófagos, principalmente na periferia de capilares e folículos pilosos. Esses achados clínicos e patológicos são semelhantes aos descritos por JACKSON et al. (1984), SCOTT et al. (1984) e PAPPALARDO et al. (2002) em casos de pênfigo foliáceo, em cabras. A doença é rara em caprinos e, aparentemente, este é o primeiro relato da enfermidade no Brasil.

Ciência Rural, v.38, n.9, dez, 2008. 


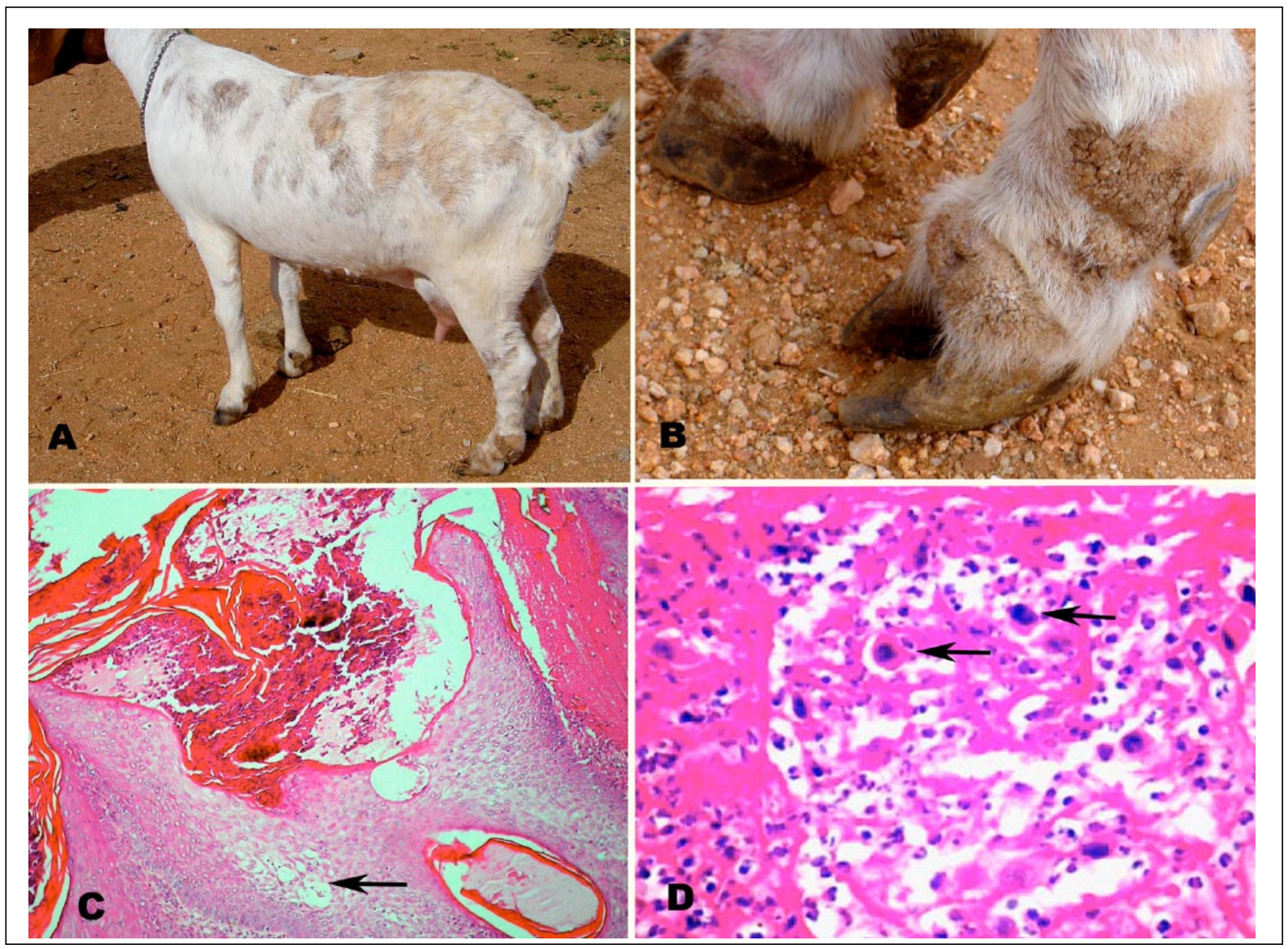

Figura 1 - Cabra. Pênfigo foliáceo. A. Observam-se extensas áreas alopécicas e bilaterais localizadas na região dorsal da escápula, no dorso, na parede do abdômen, na garupa, nos membros pélvicos e na cauda. B. Observam-se áreas irregulares alopécicas com crostas no rodete coronário e região do boleto. C. Pele. Pústula intracorneal e áreas de degeneração hidrópica com formação de vesícula (seta). H\&E. Obj 10x. D. Pele. Pústula intracorneal com neutrófilos, eosinófilos e células acantolíticas (setas). H\&E. Obj 40x.

\section{REFERÊNCIAS}

GROSS, T.L. et al. Veterinary dermatopathology: a macroscopic and microscopic evaluation of canine and feline skin disease. Mosby Elsevier: St Louis, 1992. 520p.

HARGIS, A.M.; GINN, P.E. The integument. In: McGAVIN, M.D.; ZACHARY, J.F. Pathologic basis of veterinary disease. Mosby: St Louis, 2007. Cap.17, p.1107-1261.

JACKSON, P.G.G. et al. Pemphigus foliaceous in a goat. Veterinary Record, v.114, p.479, 1984.

JONES T.C. et al. Patologia veterinária. 6.ed. Barueri, São Paulo: Manole, 2000. 1415p.

MONTEIRO G.A. et al. Pênfigo foliáceo em um eqüino Ciência Rural, v.37, n.2, p.594-598, 2007.
OLIVEIRA FILHO J.P. et al. Pênfigo foliáceo em eqüino: relato de caso. Arquivos Brasileiros de Medicina Veterinária e Zootecnia, v.59, n.5, p.1132-1136, 2007

OLIVRY T. A review of autoimmune skin diseases in domestic animals: I - Superficial pemphigus. European Society of Veterinary Dermatology, v.17, p.291-305, 2006

PAPPALARDO E. et al. Pemphigus foliaceus in a goat. Veterinary Dermatology, v.13, p.331-336, 2002

RADOSTITS et al. Veterinary medicine. 9.ed. Philadelphia: Saunders, 2000. 1881p.

SCOTT D.W. et al. Pemphigus foliaceus in a goat. Agri Practice, v.5, p.38-45, 1984.

VALDEZ R.A. et al. Use of corticosteroids and aurothioglucose in a pygmy goat with pemphigus foliaceus. J ournal of the American Veterinary Medical Association, v.207, p.761-765, 1995. 